\title{
The Economic Empowerment of the Ummah on the Basis of Productive Waqf in West Sumatra, Indonesia
}

\author{
Rozalinda ${ }^{1}$ \\ ${ }^{1}$ Lecturer at the Sharia Faculty of the State Institute of Islamic Studies \\ (IAIN) Imam Bonjol Padang, Indonesia \\ Email: rozaldi.chaniago@gmail.com
}

\begin{abstract}
West Sumatra owns a very prospective waqf asset. Yet, in general it has been managed traditionally. Only some counties have already implemented productive waqf management. This study examines the productive waqf management roles in empowering the ummah economy in West Sumatra including the supporting and inhibiting factors in implementing the productive waqf management in this province. This work is a qualitative descriptive study, which verbalizes and analyzes the data holistically. The data of this research are collected from interviews and written documents. The purpose of this research is to analyze the role of productive waqf in empowering the ummah's economy in West Sumatra as well as to elaborate the supporting and inhibiting factors in developing the waqf productive in West Sumatra. Business facilities provided by the waqf management institutions give communities more chances to get employed or to expand their businesses and gain more profits so increase their living standards as well. As a whole the waqf management in West Sumatra has gone well and got supported from most community members. The only obstacle is limited cash waqf so make it rather difficult to expand the waqf assets. Therefore in order to make the ummah economic empowerment on the basis of productive waqf becomes more effective, it is suggested that the waqf management institutions introduce a money waqf movement.
\end{abstract}

Keywords: productive waqf; rent; profit sharing; business; economic empowerment.

\section{A. INTRODUCTION}

Waqf is a charitable institution in Islam, which functionally address social and humanity issues, such as poverty alleviation and economic empowerment of the ummah. If this religious financial source has been managed professionally, it can be a mean of economic improving instrument of the ummah. It is time to move forward from the old paradigm saying that the waqf property should only be used consumptively, to a new more profitable paradigm namely productive waqf.

The productive waqf is a new developed paradigm in the waqf studies introduced by M. A. Mannan, an expert in Islamic Economy at the King Abdul Aziz University, who says that to create a pattern of productive waqf development requires a waqf management reform. According to senior researchers of Islamic Research and Training Institute (IRTI) of Islamic Development Bank (IDB), cash waqf certificate is a financial innovative effort in the waqf issues. For example, in Bangladesh the cash waqf has been proven giving opportunities for investment in religious, educational and social services. 
The fund raised from the cash waqf can be used for various purposes, including for maintaining the waqf properties and other expenses. (Abd al-Mannan, 1987).

Based on the data from the Regional Office of Indonesian Religious Ministry Affairs of West Sumatra, the wide-ranging of the waqf properties in West Sumatra reaches 7,464,575m2 located in 6,096 locations. (West Sumatra Regional Office of Indonesian Religious Ministry Affairs,2011) Unfortunately these large properties are mostly exploited traditionally. Whereas if it is managed in a productive system, it will provide more benefits which can be used to solve the ummah main problem, i.e. poverty.

This study, then, focuses on the waqf properties managed productively in different places in West Sumatra namely the Shuhada Mosque in Palangki Sijunjung, the Ansharullah Mosque in Payakumbuh, the al-Falah Mosque in Jambu Air Bukittinggi, the Jami' Mosque in Tigo Baleh Bukittinggi, the Taqwa Muhammadiyah Mosque in Padang, and the Foundation of Haji Abdullah Ahmad PGAl in Padang. These places have been chosen principally because of their strategic locations and the variety of business facilities provided by those bodies. To measure the productive waqf contributions to empower the ummah economic is by analyzing the improvement of the tenants' income at those rented waqf properties.

A large number of researches concerning waqfhave been carried out by those specialized in the sharia either on the classic figh or on Islamic economic discourses. Yet there are only a few who focus on the productive waqf study. Among these are:

Peranan Wakaf dalam Mewujudkan Kesejahteraan Sosial: Study Kasus Pengelolaan Wakaf di Jakarta Selatan (The Role of Waqf in Attaining Social Welfare: A case study on the waqf management in South Jakarta), a dissertation by Uswatun Hasanah, 1997. This dissertation examines the waqf management in South Jakarta, how has it been managed and does it give contributions to elevate the ummah economic level and to educate people. This dissertation finds out that the waqf management in South Jakarta has not yet improved as it has might been projected. The waqf properties in South Jakarta are mostly used for everyday uses, such as places of worship namely mosques and mushalla, schools and so on. These kinds of exploitation do not directly lead to the achievement of social welfare. This dissertation then inspires me to do further study on what kind of efforts can be possibly applied to enlarge the waqf properties productively. That is why this study becomes necessary.

The next study is Potensi Wakaf Uang dalam Sistem Ekonomi Islam(The Cash Waqf Potential in Islamic Economic System), a thesis by Hendra, 2002. This thesis outlines that a cash waqf can be conducted on the basis of maslahah mursalah. The urgency of the cash waqf is opening up opportunities for the wakif to give donations depending on their capabilities, increasing the capital and revenues of sharia financial institutions, promoting economic growth and equal distribution of income and also maintaining political stability. The waqf funds collected can be directly invested into real sectors or through sharia financial institutions with the principles of profit sharing, trading and leasing. This thesis becomes a starting point for such research on productive waqf and exposes a possibility to carry out a further investigation about the management of the productive waqf by means of cash waqf. 
Unfortunately these researches have not yet discussed the ummah's economy based on productive waqf. This research is to analyze the role of productive waqf on the ummah's economy empowerment in West Sumatra, and then discuss the supporting and inhibiting factors in developing the productive waqf in West Sumatra.

\section{B. METHODS}

This work is a qualitative descriptive research, which attempts to explore and analyze the data holistically regarding the role of productive waqf in West Sumatra related to the efforts to boost the economic level of the ummah. This study is a field research study applying the qualitative method to examine the data in depth.

To attain the research purposes, this work applies the following steps: (1) Surveying productive waqf management institutions in West Sumatra; (2) Examining the patterns employed in implementing productive waqf management inthis province; (3) Investigating and analyzing the contributions of the productive waqf management to empower the ummah economy within this region; (4) Finally analyzing either the supporting or inhibiting factors in implementing the productive waqf management in West Sumatra.

The data of this research are collected from interviews with waqfnazirs, mosque caretakers, board of foundations, entrepreneurs and those who get benefit from the waqf properties as well as formal documents. This raw data was then academically treated through the process of reduction, placing into display, interpreting, (Moleong, 2004) and finally drawing a conclusion.

\section{RESULTS AND DISCUSSIONS}

Referring to the multiplier effects of productive waqf as proposed by Ahmad Muhammad Abd al-Adhim al-Jamal, productive waqf gives possibilities to get employed dan reduce unemployment number in addition to participate in trading activities among the society (Al-Jamal 2007) The improvement of the society's economy as the impact of land productive waqf utilizations is qualitatively measured by examining the occurrence of significant increase in the society's income during their commercial activities at those waqf places. On the followings will be elaborated the impacts of business facilities utilization on the empowerment of the ummah's economy in the districts of the productive waqf properties.

\section{The economic productive activities of Haji Abdullah Ahmad PGAl Foundation in Padang}

As a waqf foundation engaged in religious, educational and social services, according to Yulius Said (2014), the Board Director of the AA Foundation Haji Abdullah Ahmad PGAI (AA PGAI) Foundation possess the following facilities:

a. Educational institutions from kindergarten to senior high school level with their own buildings including a sport school. These institutions have been administrated by themselves. While the Islamic High School for Qur'anic Studies (STAIPIQ) Buildings 
have been administered by LPTQ (the Qur'anic Higher Educational Institution) on the basis of a privilege to use.

b. An orphanage.

c. The Darul Ulum Mosque

d. Recidencies for their teachers and boards besides those are rented to public.

e. A soccer field.

f. The foundation secretariat office

g. Accommodation buildings and shops are leased to public for various types of businesses such as tailor, food and beverage stores, pharmacies, mobile counters, etc.

According to Darwis Kasim, the Secretariat Chief of the AA Foundation, (2014) From this land waqf covering an area of 5 hectares, the AA Foundation earns about one billion rupiahs every year. This earning is used for the foundation routine operational expenditures, such as new buildings construct, maintenance and rehabilitations, the salary of teachers, schools' employees, the foundation secretariat staffs in and the operational cost of the orphanage.

These commercial facilities provide an opportunity for tenants to earn income and meet the daily needs of their families. Edward Tailor, one of the tenants in this waqf land, said that he has rented a shop in this location since eight years ago. From his business over there he gets income to fulfill the basic needs of his family and educate their children. Yopi, a pharmacy owner, explained that it had been nine years since he has rented a building shops located directly in front of Regional M. Jamil Hospital in Padang. His business has been running smoothly and gained huge profits. Until now he has hired five employees and one pharmacist. His earning has continued to rise and also fulfill his family basic need. According to Syamsul (2014), the Beringin Restaurant owner, his parents have rented the shop from the AA Foundation since 35 years ago. From year to year their incomes continue to grow and have already employed 15 employees.

\section{The economic productive activities of the Syuhada Mosque in Palangki}

The productive waqf in the Syuhada Mosque Palangki is implemented based on a recommendation from the reviewers' team of exemplary mosque of West Sumatra province in 2009 that every mosque should have a productive economic sector. Then the community was built a commercial building of five doors. This building construction funds come from public donations in forms of zakah, infaq, sadaqah and waqf. The construction of this economic building is a program of the Syuhada Mosque Palangki accomplished by the local community hand in hand. According to Asrul Dt. Mogek Kanamoan (2014), The Chief of Palangki Village, the productive waqf program in this mosque is a communal decision of the Palangki residents.

The commercial building of the Palangki Syuhada Mosque was built on the waqf land of $2230 \mathrm{~m} 2$ next to the Mosque and leased to public. The earnings from these rented shops are added up to other Mosque revenues, i.e. zakah, infaq and sadaqah. Types of commercial activities in this location are selling daily needs, Muslim outfit, photo copies, BMT Umm el-Rahimah Palangki, the Ukhuwah products stock exchange and the Hajj and Umrah travel agency. 
The productive waqf management applied in Palangki Syuhada Mosque gives a significant contribution to the empowering of the ummah economy. This is implied from the leaseholder's testimonies. Neneng, for example, said that she gets a handsome profit from the initial capital since she has started doing business here. She spends this profit to increase her business capital and fulfill her family necessities. Murniati, (2014) the owner of the Muslims Outfits Store, stated that she feels being helped by this program. Besides the rent is cheaper than other places, her business has progressed well since she has traded in this area. From her business profit she can afford her family needs in addition to increase her business investment.

Other than zakah, sadaqah, infaq and later on the rental fees of the commercial building and the sale of the Mosque second hand stuffs, the Mosque revenue also come from Sijunjung Regency Governmental Aid and the Mosque saving interest at the financial institutions. These revenues are allocated to finance the Mosque programs. Based on financial report of the Palangki Syuhada Mosque of the year 2009-2013, the Mosque Fund had been distributed to the following sectors:

Table 1

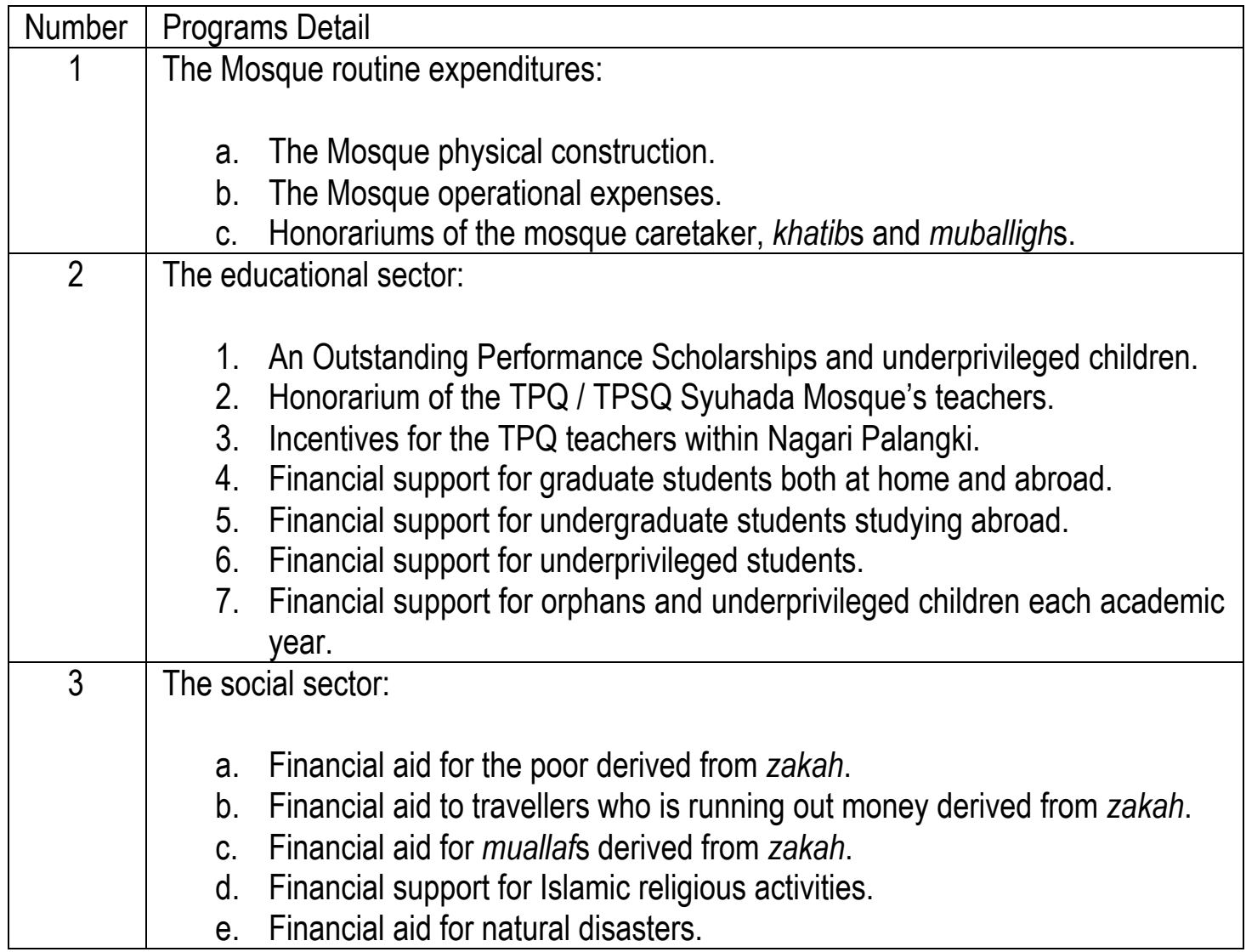

From the total expenditures of Palangki Syuhada Mosque, 55-60\% was spent to finance the Mosque routine expenses, like increasing the Mosque facilities, and the Mosque operational expenses. While the rest, about $40-45 \%$ is for non-physical budgeting such as honorariums and financial aids. The financial aids have been set only to help elementary to senior high school orphan students. University students are granted financial aids only if they are poor. 
Educational financial aids for the orphans have been awarded since 1998. Every kid in the same level of educationgets the same amount of funding. If a family has more than one child, they receive funding in accordance with their level of educations. This funding has distributed in every new academic year. According to Yati, (2014) a mother of an orphan kid, she receives funding of Rp $650,000.00$ each year for her child of an elementary school student. While Elfitri receives funding of Rp 750,000.00 for her son of junior high school student and Rp 1000,000.00 for her elder son who was a senior high school student. However, kindergarten and TPQ teachers get incentives every six months.

Unfortunately the economic empowerment in form of tutorials and financial capital has not been implemented yet at Palangki Syuhada Mosque. According to Damrulthon (2014), The secretary of Syuhada Mosque Board, that for the time being they can only provide rented places for business on the basis of ijarah, not yet in form of financial capital aids or entrepreneurial trainings.

\section{The economic productive activities of the Ansharullah Mosque in Payakumbuh}

Payakumbuh Ansharullah Mosque is one of Muhammadiyah mosque located in the Center of Payakumbuh County. This mosque was built on a waqf land area of $804 \mathrm{~m} 2$. Ansharullah mosque has become the center of religious activities in Payakumbuh and the 50 Kota District since a long time. Besides being used to perform the five daily prayers, the mosque also has a TPQ / TPSQ (Qur'anic Learning Body) and organizes religious sermons routinely. So the mosque is hardly without any visitors all day long.

Due to its strategic location, in 1985 the Payakumbuh Local Chairman of Muhammadiyah has initiated to build five stores. These stores are meant to earn more income for the mosque and the Muhammadiyah organization, in addition to facilitate small merchants. These stores are leased on the basis of ijarah and earn about Rp $9,000,000.00$ annually. $25 \%$ of this amount is allocated for the Muhammadiyah charities while the rest, $75 \%$ of it is allocated for the Mosque operational expenses. As for the needy and orphan children, disaster reliefs, incentives for teachers of Muhammadiyah educational institutions and Muhammadiyah regeneration programs, According to Bakhtiar (2014), the Treasurer of Payakumbuh Muhammadiyah Waqf Body, the organization raises funds through LAZISMU, an institution specifically manages zakah, infaq, and sadaqah collected either from the Muhammadiyah members or public.

As for the types of business run in the Payakumbuh Ansharullah Mosque complex are a barber; a travel agency of Hajj and Umrah; a Mobile Counter; a Nusantara Sport shop; and a store selling foods and drinks. According to Emi (2014) the tenant at these stores, their trading activities run well because of its strategic and busy location. There is even a tenant who has traded in there for 10 years. He did not even think to look for another place to trade because of the sales are pretty good over there.

Other than renting places for commerce, the Board of Ansharullah Mosque has not yet designed economic programs such as entrepreneurial trainings or financial capitals. Perhaps in the future they will do so in order to contribute more to the development of the ummah economy. 


\section{The economic productive activities of al-Falah Mosque in Jambu Air Bukittinggi}

The productive waqfmanagement at al-Falah Mosque in Jambu Air Bukittinggi can be regarded as an ideal model of the productive waqf management. The mosque provides facilities to be rent to the community based on leasing concept or profit sharing. Incomes from this investment all together with funds from public donations and alms are allocated for operational costs of the mosques and helping people who reserves the right (mustahik), such as the poor, orphans, disaster relief, and other socioreligious activities.

Other than rented stores and houses, al-Falah Mosque also provides a parking lot, rented home appliances for parties, and fishponds to support productive economy.

\section{a) Stores}

Al-Falah Mosque now owns seven stores. The stores construction fund came from the ummah ZISWAF (zakat, infaq, sadaqah, and waqf) that at first only about 500 million rupiahs. These stores are rented to community on the basis of leasing and profit sharing. These stores sell prayers outfits, foods and beverages, cars and helmets. Based on the financial report of the year of 2013, al-Falah Mosque earned 104 million rupiahs from these stores alone. Other than this earning, the mosque also received a share about $10 \%$ of the stores profit. This income was spent to finance the enlargement of the mosque and its operational expenses.

\section{b) Rented houses}

Al-Falah Mosque owns two tenement houses. These houses are leased to public as many as 6.5 million rupiahs each year.

\section{c) Parking lot}

From the parking lot, the Mosque earns income about 18 million rupiahs each year obtained from compulsory deposit of 50 thousand rupiahs per day.

\section{d) Home Appliances}

Al-Falah Mosque rents out household appliances for the purpose of celebrations such as circumcision ceremony, weddings party, etc.According to Yusni (2014), a Board of al-Falah Mosque, From this stuff, the Mosque earns about 3.550 million rupiahs each year.

\section{e) Fish ponds}

Al-Falah Mosque also owns a fishpond donated by the community. The product of this fishpond gives economic significance to the community. And when the harvest season comes, the community can enjoy the fish. The fishpond management hands over entirely to the Mosque Youth and caretaker. According to Nasril (2014), a Board of al-Falah Mosque, The fishpond produces between 3-5 million rupiahs annually. 
The productive waqf management brings multiplier effect into the community. Fundamentally mosque is a place of ibadah (worship), religious educations, and to enhance the communal prosperity. Using the business facilities provided by the Mosque, the community has a chance to get employed or to increase their incomes so that they can afford their family necessities. From this income, the Mosque also can cover its operational costs. The following will explain the role of managing productive waqf at the Mosque al-Falah Jambu Air Bukittinggi to the economic empowerment of the surrounding community.

\section{1) Economic actors}

The stores leased to community help them upgrading their economic level. According to Yusuf Qardhawi (2014), a Board of al-Falah Mosque, The tenants do not have to pay a big amount at once because the rent payment can be managed in installments throughout the year. Additionally the lease does not rise every year as it happens to most other stores so the tenants can run their business at ease.The location of the mosque is quite strategic because it is located on the roadside of Sumatra transverse so the visitors or buyers nearly always around, either stopping to do prayers or just to shop. This is why the tenants earn fairly large profits and hopefully increase from time to time.

\section{2) The surrounding community}

The surrounding communities also get benefit from the earnings of the mosque productive assets management because some of the income is allocated for social and educational sectors other than the mosque operational costs and caretakers salaries as it is showed by the following table.

Table 2

\begin{tabular}{|c|l|}
\hline Number & The Waqf Distribution Details \\
\hline 1 & The mosque expenses: \\
& $\begin{array}{r}\text { A. Operational Cost } \\
\text { B. The salary of caretakers, cleaning services, and teachers. }\end{array}$ \\
\hline 2 & The poor and orphan children. \\
\hline 3 & Social activities \\
\hline 4 & Tuition fee for MDA students \\
\hline 5 & Natural disaster reliefs \\
\hline
\end{tabular}

\section{The economic productive activities of the Jami‘ Mosque in Tigo Baleh Bukittinggi}

Not different from other mosques, productive economic activities in the Jami' Mosque in Tigo Baleh Bukittinggi are also in form of providing rented stores within its yard. These stores were built in 1991 as many as five stores sized $5 \times 5 \mathrm{~m} 2$. Economic activity types in this area are a photocopy, a mini market, a mobile counter, and a parking lot. These assets gain about fifteen million rupiahs annually in addition to five hundred thousand rupiahs monthly form infaqand sadaqah.

The management of productive waqf assets at the Jami' Mosque has a multiplier effects to the community in two forms: 


\section{a) Empowering community's economy}

Trading spaces provided by the Jami' Mosque offer the community an opportunity to get employ or raise the income either for shopkeepers or employees. The mosque even provides a place of residence for the caretakers in addition to monthly stipend. These prove that managing the waqf productively play a significant role in empowering the society's economy.

\section{b) Helping poor people and orphans.}

There are still numerous poor families in Nagari Tigo Baleh Bukittinggi. Those unfortunate ones get assistance from the Jami' Mosque on regular basis as many as 750 thousand rupiahs annually. While the needy students from elementary level to the university level receive an amount of 800 thousand rupiahs each for tuition fee in every beginning of a new semester. Additionally they receive one million rupiahs each in the month of Ramadan every year. The Mosque raises fund for the orphans alone about 40 million rupiahs every month.

\section{The economic productive activities of the Taqwa Muhammadiyah Mosque in Padang}

Economic program in the Taqwa Muhammadiyah Mosque in Padang is in form of providing stores leased to public. The stores' rental prices vary between 6-15 million rupiahs per year depend on its position. These stores were built in 1991 as many as 14 stores as following: 10 stores are rented to public, 3 stores are directly managed by the mosque, i.e. a barber shop, a book store, and a photocopy, on the basis of profit sharing. The rented stores are Evonel Shop, Herbal Medicine store, Rief Da printing shop, Amanah sablon, and sharia bank KJKS BMT Taqwa run by the Muhammadiyah regional board of West Sumatra. While the base of the tower's space leased for ATM center. According to Irwan Toni (2014), the vice secretary of the Taqwa Mosque, from these commercial assets, the Taqwa Mosque gains approximately 160 million rupiahs per year. Those earnings directly transfer to the Mosque Bank Account at the BMT Taqwa Muhammadiyah. This fund is allocated to finance the Mosque renovations and maintenance, to pay the electricity bill, the telephone bill, the secretariat staff salary, the teachers' salary, and the preachers' salary. This fund is not allocated to poor people and orphans because the Mosque has a separate income to tackle these two, which are the infaq and sadaqah boxes for orphans and LAZISMU Body for the poor. They collect about 500 thausand rupiahs daily from these boxes. According to Zufrizal (2014), the Treasurer of the Taqwa Mosque, The collected amount is directly distributed to the orphans in the Muhammadiyah Orphanages and schools.

\section{The Supporting and Inhibiting Factors of The Productive Waqf}

The supporting factors to the development of productive waqf properties at the mosques in West Sumatra are the followings:

\section{a) A good understanding of the waqf administration and registration.}

A good understanding of the waqf management team about the land administration and property development is very helpful to the administrative and registration process of the waqf properties. All 
productive waqf properties in West Sumatra are already registered to Badan Pertanahan Nasional (BPN; the national land affairs) and possess the waqf property certificates. With this legality the waqf management team is easily get financial assistances to multiply the waqf properties either from the government through APBD (Provincial Budget), APBN (National Budgets) or BUMN (State-Owned Enterprises)

\section{b) Support from the local government and the community}

The productive waqf implementation in West Sumatra cannot be separated from the support from local governments and communities as well as perantau (i.e. the community members who reside in other places for economic or other reasons). The Muslim society eagerly distributes their infaq, sadaqah and waqf to build mosques and intensify its' function. Beside that the local governments, the religious ministry affairs and the BUMN (State-Owned Enterprises) are also very supportive for such efforts. For example, Sijunjung local government through Grant and Social Fund (Hibah and Dana Sosial) gave donations to Palangki Mosque Renovation. So the Directorate of Waqf Empowerment of the Ministry of Indonesian Religious Affairs, The Ministry of Indonesian Educational Affairs and Semen Padang Company gave donations to the Abdullah Ahmad PGAI Foundation to build stores and school buildings.

\section{c) The strategic location of the waqf properties}

Generally the waqf properties managed productively are located in strategic locations. For example, Palangki Syuhada Mosque and Jambu Air Al-Falah Mosque in Bukittingi are in the roadside of Sumatra-transverse. Their big yards make it possible to build stores. Some mosques are located in downtown, very close to the trading center like Ansarullah Mosque in Payakumbuh and Taqwa Mosque in Padang which just only in a walking distance. Of course this is very supportive to the productive waqf management because these locations are always very crowded during the day, especially during rush hour. Lots of people come to the mosque to do prayers or just pass by. The trading activities run well and the tenants earn good incomes, in consequence the waqf assets increase progressively as recognized by Arniadi, one of the lessees at the Taqwa Muhammadiyah Mosque in Padang. According to him, that store is a branch of his bigger store located at Pasar Raya Padang. Yet, this store gives him more income because more people do shopping there then that the circulation of merchandise was faster over here. So do the assets of Abdullah Ahmad PGAI Foundations which provides rented houses, shops and schools, are also located in the city center, close to the building of government institutions, hospitals, and offices. Public can easily access these facilities and most of the tenants sign a lease for a long period. The main reason for this is the high frequency of commercial transactions.

\section{d) Public trust}

Public contribution and consciousness to donate some of their wealth to build a mosque are quite high due to their trust upon the Board of the mosques. This trust is based on the trustworthy and the transparency of the Board. The mosque financial management is reported every Friday before the Friday Prayers weekly, monthly or annually. The financial management of the mosque is well managed, transparent and accountable. The cash flow statements clearly written on whiteboard, so 
that the mosque congregation's trust to give infaq, sadaqah, zakah and waqf to the LAZIS of the mosque is reasonably high. This is mostly because the Board is among prominent figures within the community like alim ulama (religious leaders), ninik mamak (clan leader), and cadiak pandai (a wise man) so make it easier to manage the waqf properties productively.

\section{e) A solid and unified vision of the waqf properties management team.}

Last but not least, a solidity and unified vision of the waqf management team is also very important to improve the waqf management system. It is the most important factor in managing waqf properties productively. Without it surely the productive waqf property development program will not be implemented properly. Different opinions are human but the decision must be made on the basis of consideration and consensus (musyawarah dan mufakat).

Additionally most of the waqf properties are belong to Nagari, like Palangki Syuhada' Mosque and Tigo Baleh Jami' Mosque. Everything related to the mosque actions plan is discussed in Nagarimeeting, which usually placed in the mosque. Every element of the society, like Board of the mosque, ninik mamak, alim ulama, cadiak pandai, wali nagari (the chief of the village), the head of the sub district, the chief of the local religious ministry affairs, are involved in making decision process of the waqf properties improvement.

Generally the respondents of this research said that they have not found significant obstacles in developing the waqf properties productively. Every elements of the society is very supportive to the actions plan of the mosque board. According to Damrulthon (2014), the Secretary of Syuhada Mosque, if there is disagreement among the committee, they resolve it through deliberation and consensus.

The main obstacle in improving productive waqf properties is limited fund so business facilities construction has progressed a bit slowly. According to Afrison Saleh (2014), the Board Leader of the Syuhada Mosque, even sometimes they have to stop the construction of the facilities for a while and then continue the construction after raising a sufficient fund.

Funding issue in improving the productive waqf properties experienced by the productive waqf management team in West Sumatra actually can be resolved by promoting cash waqf. The waqf nazhir (committee) collect donations from society members in any amount. This fund will be invested to build stores, which then rented to public. The waqf fund also can be distributed in form of financial capital on the basis of mudarabah muqayyadah (profit sharing).

The productive waqf at least can be in two ways: cash waqf and stock waqf. Cash waqf is a new paradigm in the waqf management. Mannan said that cash waqf is an innovative effort in the field of Islamic public finance. Cash waqf opens investments in religious programs, education, and social services. We can take advantages from the public saving by exchanging it into cash waqf certificate. The earning from the cash waqf management can be used for many purposes including the maintenance of the cash waqf. (MA Mannan, 1999) Moreover cash waqf also functions as a strategic investment to reduce poverty number, as well as to provide educational, health and social infrastructures. (Masyita dkk, 2003) 
Cash waqf, in addition to other Islamic financial instruments like zakah, if it is managed productively can be benefitted to improve the living standard of the society. This means that waqf become the funding resources from the ummah and used for the benefit of the ummah either to tackle religious, social or economic issues. In order to accomplish such purpose, it is important to socialize it as well as make it as the ummah collective movement.

Cash waqf management has a unique character. Conceptually it is different from western charity and donations. Waqf has a timelessness principle. It should be preserved and only its benefit can be distributed to the public for the sake of religion and righteousness. This is the main reason why cash waqf should be managed on the basis of professionalism, transparency, and accountability. (Setiawan Budi Utomo, 2008)

Based on this mindset Muhammad Anas Zarqa', an expert in the Center of Islamic Economic Research at the King Abdul Aziz University, said that waqf management must present a good performance. The Nazhir must manage the awqaf projects on profitable financing sectors and consider high profit investments, which are in accordance with the sharia principles. (Zarqa', 1987.)

Accordingly Monzer Kahf said that in order to decide a good awqaf management, what should be defined firstly is the target of the awqf projects. The waqf manager has to take a part in the awqaf projects so that he can supervise his teamwork effectively. According to him cash waqf can be implemented in three ways. (Kahf, 2000)

Firstly, the waqf institution receives cash waqf to finance certain awqaf projects. Then the earnings or the profits are distributed to the mawquf 'alaih like orphanages, orphans, poor people, etc. In this case, the waqf institution acts as a nazhir of the cash waqf. The waqf institution can also directly invest the money to corporates or commercial institutions, sharia banks or other sharia financial institutions on the basis of mudarabah or ijarah principle.

Secondly, cash waqf is invested in form of wadi'ah or mudarabah by the wakif at certain Islamic banks or other financial institutions. In this case, the wakif directly acts as a nazhir of the money he donated by investing and at the same time making profit from the money invested. The profit then is to be distributed to the mawquf 'alaih.

Thirdly, cash waqf is used to finance productive awqaf projects which earnings then are distributed to the mawquf 'alaih. Managing cash waqf in this model needs a committee to collect cash waqf and to build waqf fascilities. For example, a Muslim community wants to raise fund to build a mosque, a hospital, an orphanage, etc. Thus they establish a committee to collect donations and build each project. The money collected is lawfully declared as a waqf ever since.

\section{CONCLUSIONS}

Business facilities built on the waqf lands leased to public, give communities a chance to get employ or to increase their incomes and to improve their living standards as well. Basically, the management of productive waqf in West Sumatra has found no substantial problems because this program gets support from every element of the society, i.e. inhabitants, clan leaders, religious leaders and the local 
government. The only problem is the limitation of cash waqf to enlarge the productive waqf assets. In order the societal economic empowerment run effectively, it is suggested to promote a Massive Cash Waqf Movement to intensify productive waqf assets usage, which then leads to increase mosques revenue and more people will get assisted. 


\section{References}

Abd al-Mannan, Muhammad. 1987. "Cash Waqf Certificate Global Opportunity the Social Capital Market in 21st Century Voluntary-Sector Banking." In Proceeding Ofthe Third Harvard University Forum on Islamic Finance, Cambridge, Massachussets, Harvard University.

Al-Jamal, Ahmad Muhammad Abd al-'Azhim. 2007. Dawr Nizam Al-Waqf Fi Al-Tanmiyah AlIqtishadiyah Al-Mu'as\}irah. Cairo: Dar al-Salam.

Kahf, Monzer. 2000. Al-Waqf Al-Islami: Tathawwaruh, Idaratuh, Tanmiyatuh. Damascus: Dar al-Fikr.

Masyita, Dian, and dkk. 2003. "A Dynamic Model for Cash Waqf Management as One of the Alternative Instruments for the Poverty Alleviation in Indonesia." Islamic-world.net. .

Moleong, Lexy J. 2004. Metodologi Penelitian Kualitatif. Jakarta: Rosda Karya.

"West Sumatra Regional Office of Indonesian Religious Ministry Affairs." n.d. In Rekapitulasi Perkembangan Sertifikat Tanah Wakaf Sumatera Barat Tahun 2011.

Zarqa', Muhammad Anas. 1987. "Financing and Investment in Awqaf Project: A Nontechnical Introduction." March 14, 2008. www.islam.co.za/awqafsa/source/library/article.

Abd al-Mannan, Muhammad. (September 30 - October 2,1999). Cash Waqf Certificate Global Opportunity the Social Capital Market in 21st Century Voluntary-Sector Banking. Proceeding ofthe Third Harvard University Forum on Islamic Finance, Cambridge, Massachussets, Harvard University.

(1987). The Institution of Waqf: Its Religious and Socio-Economics Roles and Implications in Management and Development of Awqaf Properties, Proceeding Seminars (Jeddah: Islamic Research and Training Institute, Islamic Development Bank.

Ahmed, Habib. (2004). Role of Zakat and Awqaf in Poverty Alleviation. Jeddah: Islamic Research and Training Institution, Islamic Development Bank.

Amin, Muhammad Muhammad. (n. d). Al-Auqaf wa al-Hayat al-litima'yah fi Mishr. Cairo: Dar alNahdhah al-'Arabiyah al-Qahirah.

Bamualim, Chaider S and Irfan Abu Bakar, (2005). Revitalisasi Filantropi Islam: Studi Kasus Lembaga Zakat dan Wakaf Indonesia. Jakarta: Center for Study of Religion and Culture.

, (2006). Islamic Philantrophy \& Social Development in Contemporary Indonesia. Jakarta: Center for Study of Religion and Culture.

, (2005). Filantropi Islam\& Keadilan Sosial: Studi tentang Potensi, Tradisi dan Pemanfaatan Filantropi Islam di Indonesia. Jakarta: Center for Study of Religion and Culture.

Basa, Muhammad Qadri. (2006). Qanun al-'Adl wa al-Inshaf fi al-Qadha 'ala Musykilat al-Awqaf. Cairo: Dar al-Salam. 
Chapra, Muhammad Umer. (2001). The IslamicFoundation. Translated by. Ikhwan Abidin Basri. Yayasan Islam. Jakarta: Gema Insani Press.

, (2001). The Future Of Islamic Economis: An Islamic Prespectives. Translated Ikhwan Abidin Basri. Masa Depan IImu Ekonomi: Sebuah Tinjauan Islam. Jakarta: Gema Insani Press.

Cizakca, Murat. (1998). Awqaf in History and Its Implications for Modern Islamic Economic, Islamic Economic Studies. Volume 6. Number 1. Jeddah: Islamic Research and Training Institution Islamic Development Bank.

Daghi, Ali Muhyiddin al-Qurrah. (February 25, 2008). Istitsmar al-Waqf wa Thuruquh al-Qadimah wa al-Haditsah. www.islamonline.net/Arabic.

Donna, Duddy Roesmara dan Mahmudi. (June 18, 2007). The Dynamic Optimization of Cash Waqf Management: An Optimal Control Theory Approach. http://psekp.ugm.ac.id.

Hasanuddin Ahmed and Ahmedullah Khan. (1998). Research Paper. Strategies to Develop Waqf Administration in India. Jeddah: Islamic Development Bank, Islamic Research and Training Institute.

Hashmi, Sherafat Ali. (1987). "Management of Waqf: Past and Present' in Management and Development of Awqaf Poperties. Seminar Proceeding. Jeddah: Development Bank, Islamic Research and Training Institute.

Development Bank, Islamic Research and Training Institute. Management and Development Awqaf Properties. Seminar Proceeding in August 4-6, 1984. Jeddah: 1987.

Al-Ja'ali, Muhammad al-Taijani Ahmad. (2002). Al-Ittijahat al-Mu'ashirah fi Tathwir al-Istitimar al-Waqf. Riyadh: al-Mamlakah al-'Arabiyah al-Su'udiyah.

Al-Jamal, Ahmad Muhammad Abd al-'Azhim. (2007). Dawr Nizam al-Waqf fi al-Tanmiyah allqtishadiyah al-Mu'as\}irah. Cairo: Dar al-Salam.

Masyita, Dian dkk. (2003). A Dynamic Model for Cash Waqf Management as One of the Alternative Instruments for the Poverty Alleviation in Indonesia. Islamic-world.net.

Moleong, Lexy J. (2004). Metodologi Penelitian Kualitatif. Jakarta: Rosda Karya.

Mudzakkir, M. Djauzi. (1986). Teori dan Praktek Pengembangan Masyarakat. Surabaya: Usaha Nasional.

Kahf, Monzer. (2000).Al-Waqf al-Islami: Tathawwaruh, Idaratuh, Tanmiyatuh. Damascus: Dar al-Fikr. ,(March 2, 1998). Financing the Development of Awqaf Property. http://www.monzer.kahf.com. 
, (October 1, 1998). Toward the Revival of Awqaf: A Few Fiqh Issues to Reconsider. http://www.monzer.kahf.com.

, (August, 1997). Al-Asalib al-Haditsah fi Idarat al-Awqaf. http://www.monzer.kahf.com.

, (May 1, 2004). Shuar Mustajidah min al-Waqf. http://www.monzer.kahf.com.

,Al-Waqf fi al-Mujtama' al-Islami al-Ma'ashir. http://www.kantkji.org.

West Sumatra Regional Office of Indonesian Religious Ministry Affairs, Rekapitulasi Perkembangan Sertifikat Tanah Wakaf Sumatera Barat tahun 2011.

Zarqa', Muhammad Anas. (March 14, 2008). Financing and Investment in Awqaf Project: A Nontechnical Introduction. www.islam.co.za/awqafsa/source/library/article.

Al-Zuhaili, Wahbah. (1981). Al-Fiqh al-Islami al-Islami wa 'Adillatuh. Beirut: Dar al-Fikr. , (1998). Al-Washa wa al-Waqfu fi al-Islam. Beirut: Dar al-Fikr al-Mu'asir. 